ва, капитала и обязательств) подменяется содержание (сделки, действий или бездействия, которые привели к такому состоянию). Основная проблема связана с возможной недостоверностью данных учета и отчетности, поэтому, хотя выявление признаков криминального банкротства относят к финансово-экономической экспертизе, практически невозможно получить верный результат, не проводя бухгалтерскую экспертизу.

Сложившаяся неопределенность в этих и некоторых других вопросах не способствует выявлению запрещенных деяний в сфере банкротства, что вызывает необходимость совершенствования системы противодействия криминальным банкротствам.

\title{
НЕДОБРОСОВЕСТНАЯ КОНКУРЕНЦИЯ
}

Хмелева М. А., Белорусский государственный университет Научный руководитель: О. В. Лазаренкова

Актуальность вопроса защиты от актов недобросовестной конкуренции для субъектов хозяйствования Республики Беларусь обусловлена, на наш взгляд, отсутствием устоявшихся традиций корректного поведения на рынке со стороны отечественных субъектов предпринимательской деятельности.

Республика Беларусь располагает системой норм, направленных на охрану конкуренции, определен порядок привлечения нарушителей к ответственности. Проблема в том, что эти нормы «мертвы», а правоприменительная практика не столь многочисленна.

Хотелось бы отметить ряд проблемных вопросов по рассматриваемой теме.

Во-первых, законодатель поспешно относит недобросовестную конкуренцию к объектам интеллектуальной собственности, слепо следуя букве Парижской конвенции по охране промышленной собственности, расположив соответствующую главу 68 Гражданского кодекса Республики Беларусь (далее - ГК) в разделе V, именуемом «Интеллектуальная собственность», чем вводит в заблуждение относительно правовой природы данного явления. Представляется логичным, на наш взгляд, нормы, посвященные правовому регулированию недобросовестной конкуренции, объединить в самостоятельный раздел ГК.

Во-вторых, анализ нового Закона Республики Беларусь «О противодействии монополистической деятельности и развитии конкуренции» от 12 декабря 2013 г. и ранее действовавшего Закона от 10 декабря 1992 г., дает основания признать, что законодатель тщетно пытается урегулировать в едином нормативном правовом акте два института конкурентного права, при этом уделяет особое внимание монополистической проблематике и оставляет без рассмотрения эффективность регулирования недобросовестной конкуренции. Это прослеживается в ограниченном количестве норм. 
B-третьих, ввиду наличия конкуренции в вопросах подведомственности рассматриваемой категории споров между административными и судебными органами, видится целесообразным внести правовую ясность по данному вопросу в соответствующие законодательные акты. При этом обратить особое внимание правоприменителя, что по сложным делам о недобросовестной конкуренции для субъекта хозяйствования наиболее эффективным будет первичное обращение в антимонопольный орган, а затем, если потребуется, в суд.

В-четвертых, касаясь вопроса административной ответственности за совершение актов недобросовестной конкуренции, отметим, что Кодекс Республики Беларусь об административных правонарушениях (далее КоАП) в целом и ст. 11.26 КоАП «Незаконное использование деловой репутации конкурента» в частности не предоставляют на сегодняшний день юридическим лицам возможности защитить свою деловую репутацию в административном процессе от распространения порочащих недостоверных сведений. Механизм такой защиты существует только в рамках уголовного судопроизводства в рамках ст. 249 Уголовного кодекса «Дискредитация деловой репутации конкурента». В связи с этим предлагается разработать аналогичную норму об административной ответственности за дискредитацию деловой репутации конкурента и внести ее в качестве отдельной статьи в КоАП, разграничив при этом уголовно-наказуемый и административно-наказуемый составы по характеру последствий.

Таким образом, очертив немало спорных вопросов, касающихся заявленной проблематики отношений, складывающихся в сфере недобросовестной конкурентной борьбы, на наш взгляд, назрела объективная необходимость в обобщении на уровне акта Верховного Суда Республики Беларусь правовой регламентации рассматриваемого института конкурентного права в целях единообразного правоприменительного подхода к нему.

\section{ИНФОРМАЦИОННЫЕ ТЕХНОЛОГИИ В НАЛОГОВЫХ ПРАВООТНОШЕНИЯХ}

Швед А. А., БИП - Институт правоведения

Научный руководитель: канд. юрид. наук О. Г. Станкевич

В настоящее время информатизация охватила практически все сферы жизнедеятельности человека и является приоритетным направлением развития общества. Налоговые правоотношения не стали исключением.

На всех уровнях системы налоговых органов используются передовые информационные технологии. Они позволяют эффективно функционировать налоговой системе в каждой стране. Для совершенствования автоматизации функций налоговых органов, создаются автоматизированные информационные системы (далее - АИС). С их помощью обеспечивается своевременный сбор налогов и иных обязательных платежей в бюджет и 